Hva kan hverdagslige møter mellom minoritet og majoritet si om situasjonen for Tyrkias største minoritet, kurderne? Unge kurdere i Istanbul er kreative i håndteringen av egen etnisk identitet i møtet med den tyrkiske majoriteten: De skaper rom for kurdiskhet, samtidig som de unngår konfrontasjon. Paradoksalt nok kan strategiene deres føre til mindre reell dialog på tvers av etniske skillelinjer.'

\title{
Etnisk identitet som sosialt stigma?
}

STRATEGIER HOS KURDISK MINORITETSUNGDOM I ISTANBUL 
TEKST: Katrine Ree Holmøy

HVORDAN ER DET ^ VÆRE ung kurder i Istanbul? Det var ut fra denne problemstillinga jeg reiste på et sju måneders feltarbeid til Istanbul våren 2005, og det er dette jeg vil gi et forsøksvist svar på i denne artikkelen.

Flertallet av verdens kurdere bor i området som ofte kalles Kurdistan, fordelt mellom Irak, Iran, Tyrkia og Syria. Konflikten mellom tyrkiske myndigheter og den kurdiske minoriteten har pågått siden etableringen av republikken Tyrkia i I923. Siden tidlig 8o-tall har konflikten mellom kurdere og tyrkiske myndigheter kommet til uttrykk gjennom рккs bevæpnede motstandskamp.

Mange av Tyrkias kurdere satte sin lit til landets forhandlinger om medlemskap i EU. Et av de såkalte Københavnkriteriene, som definerer krav til potensielle nye medlemsland, inneholder et krav om at landets minoriteter skal beskyttes. I oktober 2006 ble konferansen The Third International Conference on EU, Turkey and the Kurds avholdt i Brussel i regi av Eu Turkey Civic Commision. Temaet var rettferdighet, dialog og løsning, og konferansen konkluderte med å oppfordre Tyrkia og medlemslandene i Eu til å finne plattformer for dialog mellom tyrkiske myndigheter og landets kurdiske befolkning. Basert på erfaringer fra kurdisk hverdagsliv vil jeg vise hvorfor denne utfordringen dreier seg om mye mer enn å få tyrkiske myndigheter til å gå i dialog med de kurdiske organisasjonene: Den dreier seg om å finne møtepunkter for tyrkere og kurdere i hverdagslivet. Uten det framstår politiske løsninger på høyere nivå som utopiske.

Hoveddelen av Tyrkias kurdere bor fremdeles i den sørøstre delen av Anatolia, i regionen som grenser mot Iran, Irak og Syria. Det bor kurdere i alle disse landene, men i denne artikkelen er det kurderne i Tyrkia som er i fokus, nærmere bestemt de som har slått seg ned i Istanbul - langt fra de kurdiske kjerneområdene. Kurderne har blitt undertrykket og nektet kulturelle og språklige rettigheter i alle de fire landene, noe som har medvirket til en voksende kurdisk diasporabefolkning utenfor regionen. Samtidig har det ført til forflytninger, både frivillig og under tvang, innad i de fire landene. Istanbul omtales som den byen i verden med flest kurdere. ${ }^{2}$ Istanbul ligger helt $i$ andre enden av Tyrkia, det er en metropol på grensa mellom Asia og Europa. Det kan sammenlignes med samenes situasjonen her hjemme hvor samene bor i området som deles av Norge, Sverige, Finland og Russland. Oslo, som er Norges største sameby, ligger i sør - langt fra det samiske 
kjerneområdet. Nettopp det at Istanbul ligger utenfor det kurdiske kjerneområdet var noe av grunnen til at jeg valgte å fokusere på den kurdiske befolkningen der. Jeg var opptatt av å se hvordan kurdere i Istanbul rekonstruerer kurdisk identitet $i$ en by hvor de er en klar minoritet. Men før jeg går videre til mine kurdiske informanters konstruksjon og kommunisering av kurdisk identitet, vil jeg gi et eksempel på hvordan forholdet mellom Istanbuls kurdere og den tyrkiske majoriteten kommer til uttrykk i offentligheten.

Den 2I. mars 2005 var det newrozfeiring i Istanbul. Newroz er kurdernes nyttår, og blir feiret av kurdere i hele Tyrkia. Det er bare noen få år siden feiringen ble tillatt, den har blitt sett som et symbol på den kurdiske motstanden og nært koblet til PKKS

\section{Det er innenfor en spent politisk kontekst mine informanter håndterer sin kurdiske identitet.}

væpnede kamp for kurdisk frigjøring. ${ }^{3}$ I en stappfull minibuss med festkledde, syngende kurdere nærmet vi oss arenaen for feiringa, en åpen plass i Zeytinburnu, et stykke utenfor sentrum av Istanbul ved kysten, der Bosporus-stredet går over i Marmarahavet. Det var en grå, forblåst dag, og rå sjøluft gufset imot oss. Inngangen til plassen der feiringen foregikk var bevoktet av tyrkisk politi som også hadde poster rundt hele plassen. Et politihelikopter svevde i lufta over mens vi ventet i kø for å bli ransaket og sluppet inn til mengden. Det ble i ettertid anslått at Ioo.000 mennesker deltok i feiringa. En stor scene var satt opp, hvor politikere fra Dehap, ${ }^{4}$ som det kurdiske partiet het i 2005 , holdt taler innimellom kulturelle innslag. Plakater med bilde av Abdullah Öcalan, den fengslede ркк-lederen, ble holdt opp side ved side med bilder av mennesker som var savnet eller hadde mista livet i trefninger med tyrkisk militære og jendarmeri. Mange bar pannebånd i de kurdiske fargene, rødt, gult og grønt, en del kvinner hadde lange, fargerike kjoler og hodekleder av det tradisjonelle slaget: i bomull med små, heklede blomster langs kantene. Det ble danset, sunget, spilt og skreket. Unge hoppet tradisjonen tro over brennende bål. Framme ved scenen løftet unge menn hverandre opp på skuldrene mens de vaiet med det kurdiske flagget og ropte «Lenge leve Apo», som er kallenavnet til Öcalan.

Her var kurdiske symboler og åpen motstand mot det tyrkiske regimet ikke lagt skjul på. Hva kan leses ut av dette med tanke på dialog mellom kurdere og tyrkere, og kurdernes posisjon i det tyrkiske samfunnet? Newroz-feiringen kan ses som et soleklart tegn på at tyrkiske myndigheter anerkjente at det var nødvendig å gi landets minoriteter større frihet. Landet var midt oppe $\mathrm{i}$ forhandlinger med $\mathrm{EU}$ om å starte forhandlinger om EU-medlemskap, og respekt for etniske minoriteters språklige og kulturelle rettigheter er en del av Københavnkriteriene fra I993 som er med på å avgjøre om et land er klart til å bli tatt opp i EU. Men betyr denne feiringa at den kurdiske befolkningen i Istanbul blir akseptert, eller at det er dialog mellom partene i konflikten? Ikke nødvendigvis. Dramaturgien rundt feiringa viser tydelig hvem som definerer når, hvor og hvordan Istanbuls kurdere får gi uttrykk for etnisk identitet og motstand: Tyrkiske myn- 
digheter rammet bokstavelig talt inn begivenheten med politi langs alle gjerder og i lufta. Det var de som bestemte hvem som slapp inn, og de kunne valgt å avbryte arrangementet. Det var de som satte grensene for dette uttrykket for kurdisk identitet i det offentlige rom.

Mediene rapporterte at newrozfeiringa var fredelig over hele landet, bortsett fra i Mersin, en by ved den nordøstre kysten av Middelhavet. Her hadde tre tenåringsgutter på I2, I4 og I5 år prøvd å tenne på et tyrkisk flagg under feiringa. De ble umiddelbart arrestert. I dagene som fulgte ble Istanbul farget rødt av tyrkiske flagg. Enorme flagg dekket hele bygninger, og i butikker, drosjer, biler, busser og kafeer ble det hengt opp tyrkiske flagg. Det tyrkiske militærets generalstab definerte guttenes flaggbrenningsforsøk som forrædersk, ${ }^{5}$ den kurdiske politikeren Leyla Zana, da i Dehap, fordømte flaggbrenningen og oppfordret til respekt for Tyrkias nasjonalsymboler. Det samme gjorde Dehaps daværende leder Tuncer Bakirhan. Myndighetene og militæret oppfordret befolkningen til å vise solidaritet med landets flagg. Nyhetsbyrået AFP meldte at markeringen av det tyrkiske flaggets ukrenkelighet «surpassed even the most patriotic Independence Day displays. Balkonies, verandahs, windows, taxis, city buses, banks and businesses here [in Istanbul] and in other major cities - even the vast, labyrinthine covered bazaar in Istanbul - are festooned with the star and crescent emblem.»

ввС rapporterte at fagforeninger og lokale myndigheter delte ut og hengte opp flagg. En spaltist i den tyrkiske avisa Radikal skrev at hendelsene reflekterte voksende anti-kurdisk rasisme i Tyrkia, og at det var nødvendig å få en åpen, offentlig debatt om dette for å finne en løsning på problemet.?

Noen dager etter newrozfeiringa satt jeg på det kurdiske kultursenteret i en av Istanbuls travleste handlegater, Istiklal Caddesi. Plutselig lød slagord opp fra gata, og vi så menn med store tyrkiske flagg som nærmest løp gjennom folkemengden, mens de ropte i kor. Når det er demonstrasjoner i denne gata, er politioppbudet som regel massivt. Denne dagen var det ikke en politimann i sikte. Noen kurdiske menn på bordet ved siden av forklarte at mennene i gata var tyrkiske nasjonalister, og at politiet sjelden grep inn når de inntok gatene. Sammenlignet med politiframmøtet på kvinnedagen 8. mars samme år, var politiets fravær påfallende.

Mitt fokus var hele tiden kurderes hverdagsliv, og gjennom det mener jeg å gripe noe av det som gjør at plattformen for dialog som EUTCC etterlyser er så fraværende. Når det er sagt, er det viktig å ha newrozfeiringa og den påfølgende maktdemonstrasjonen, som flaggopphengingen må sies å være, i bakhodet: det er innenfor en spent politisk kontekst mine informanter håndterer sin kurdiske identitet, og det er hele tiden som del av en minoritet $i$ et Tyrkia der nasjonalfølelsen fremdeles kan vekkes med voldsom styrke av tre tenåringsgutter som går over streken.

Før vi går videre til kurdernes hverdag, vil jeg ta enda et stopp innom Vest-Finnmark på I960-tallet. Det er nemlig flere innsikter fra samenes verden som kan kaste lys på kurdernes situasjon. I ig69 kom Fredrik Barths innflytelsesrike antologi «Ethnic Groups and Boundaries - The Social Organization of Culture Difference» ut, en liten samling artikler som skulle vise 
seg å endre måten sosialantropologer tenker rundt etnisitet og interetniske relasjoner, gjennom et skifte av fokus fra gruppas kjerne eller essens til et fokus på grensene mellom grupper, og hvordan disse grensene produseres og reproduseres. En av artiklene i samlinga var Harald Eidheims "When Ethnic Identity is a Social Stigma”, basert på Eidheims feltarbeid blant kystsamer i Vest-Finnmark. Han viser hvordan samisk identitet, som i det

\section{mom \\ De var smertelig klar over at de skjulte sin kurdiske identitet $i$ møtet med majoriteten.}

lille samfunnet han studerer er det han kaller "illegitim" og knyttet til en form for stigma, ikke spilles ut i interetniske relasjoner. I dette samfunnet kan etnisk tilhørighet, om man er nordmann eller kystsame, ikke avgjøres ut fra utseende, noe som gir kystsamene muligheten til å velge om de vil gi uttrykk for sin etniske tilhørighet eller ikke. Det samme kan sies om den kurdiske identiteten i Tyrkia. Det finnes mange med kurdiske aner som ikke ser på seg selv som kurdere, eller som velger å skjule sin kurdiske identitet. Noe av grunnen er at det å være åpen om tilhørighet til landets kurdiske minoritet raskt kobles til en idé om kurderne som separatister og dermed en trussel mot det landsfaderen, Tyrkias første president Mustafa Kemal Atatürk, omtalte som Tyrkias udelelige enhet. A tilkjennegi sin kurdiske identitet er på ingen måte en nøytral posisjon, uavhengig av individuelle agendaer og personlig tilhørighet.
Eidheim skisserer opp tre sfoerer for å vise hvordan samene i den lille kystbygda håndterer sin etniske tilhørighet: en lukket samisk sfære, en offentlig sfære og en lukket norsk sfære. Når han kaller dem lukkede er det ikke fordi det ikke er kontakt og kommunikasjon på tvers av grensene. Det er heller snakk om situasjonsdefinisjoner: en lukket samisk sfære innebærer at det er trygt å være åpen om etnisk tilhørighet. Denne lukkede samiske sfæren kan forekomme i private hjem, men også i det offentlige rom all den tid alle som er innen hørevidde, anses som trygge, til å stole på. Den lukkede samiske sfæren går over i en offentlig sfære idet det kommer nordmenn eller fremmede innen hørevidde. Et av Eidheims etter hvert velkjente eksempler dreier seg om samer på en lokal ferge som snakker samisk med hverandre. Idet det kommer en nordmann innen hørevidde, bytter de til norsk. Den lukkede samiske sfæren har gått over i en offentlig sfære der deres samiske identitet underkommuniseres. Eidheim tolker dette som en måte å unngå stigmaet som ligger i den samiske identiteten i møter med den norske majoriteten. Den lukkede norske sfæren kan oppstå når bare nordmenn er til stede: da kan de si hva de egentlig mener om den samiske delen av befolkningen, skriver Eidheim.

Hva har så dette med unge kurdere i Istanbul å gjøre? I min erfaring er parallellene mange. Gjennom tre eksempler vil jeg vise hvordan kurdere som er ulikt posisjonert i det tyrkiske samfunnet, veksler mellom ulike sfærer: den lukkede kurdiske sfæren og en offentlig sfære. Jeg vil ikke her se på den lukkede tyrkiske sfæren. De

Ungdommer på gaten i Istanbul. 


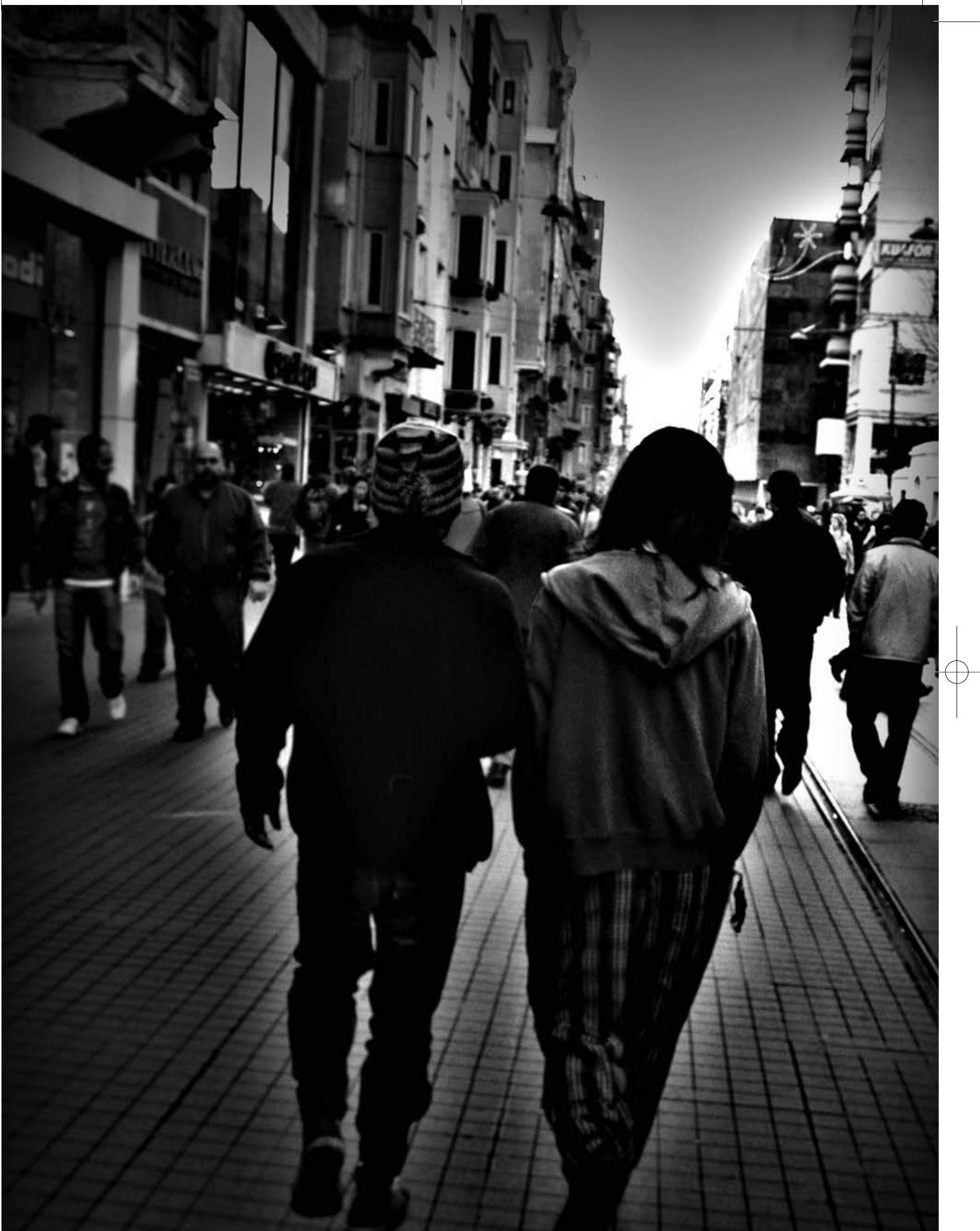


tre eksemplene handler om (I) Özlem og Gülhan sine kafévaner i Taksim, Istanbuls shopping- og kafésentrum, (2) studenten Mehmets hverdag på universitetet og (3) Ayfles liv i en av Istanbuls slumbydeler. Måten disse fire unge kurderne håndterer sin etniske identitet på i møte med den tyrkiske majoriteten varierer, og viser ulike måter kurdere i Istanbul unngår stigma og lager rom for å være kurdisk i en tyrkisk storby.

Özlem og Gülhan er i slutten av 20-åra og jobber i administrasjonen $i$ en tyrkiskspråklig, kurdisk avis. De beskriver seg selv som kurdere og anser seg som del av et politisk prosjekt for å bedre kurdernes situasjon. Vi møttes noen ganger i uka, først i avisas lokaler, men etter hvert stadig oftere på kafeer i området. Vi gikk på små kafeer, om det så var til lunsj eller på kveldstid, og innehaverne av kafeen, eller i det minste de som jobba der, var bestandig kurdere. Mine to venner presenterte dem til meg som kurdere, eller det kom fram gjennom valg av samtaleemne: planer om en dam i de kurdiske områdene som ville legge historiske Hasankeyf under vann, ble tolket inn i konteksten av den tyrkiske statens overgrep mot landets kurdiske befolkning, spørsmålet om morsmål i skolen og de nyåpnede kursene i kurdiske språk som nettopp var åpnet, var noen av temaene som definerte situasjonen som en lukket, kurdisk sfære. Det signaliserte at det var trygt å være åpen om kurdisk identitet.

Nå er det ikke noe uvanlig i å velge å gå på kafeer hvor man treffer kjente eller kjenner betjeningen. Men i Istanbul var det etniske elementet $\mathrm{i}$ valget av sted å gå påfallende. Med tyrkiske venner gikk jeg aldri på de samme kafeene, men gjerne til en annen kafé i samme bygning - bare i en annen etasje. Området rundt Istiklal Caddesi og Taksim er overfylt med restauranter, kafeer, butikker og utesteder, og befolkningen er sammensatt. I tillegg kommer folk fra hele Istanbul hit for å shoppe, gå på kafé eller møter i politiske partier eller organisasjoner som har kontorer i området. Man skulle tro at når mange mennesker med ulik etnisk og politisk tilhørighet kommer sammen på et lite område, så vil det bidra til dialog mellom de ulike grupperingene. Eksempelet Taksim viser at det ikke nødvendigvis er tilfellet. Mine informanter manøvrerte seg til sine egne, lukkede kurdiske sfærer innenfor det mangfoldige Taksim, og kommunikasjonen med mennesker som ikke definerte seg som del av den kurdiske befolkningen, var på et minimum. En kveld ringte Özlem og spurte om vi skulle møtes. Jeg hadde allerede planer, og spurte om hun ville være med. Hun sa nei. Jeg forklarte at jeg skulle treffe andre utlendinger, og hvilken kafé vi skulle på. «Den kafeen er kurdisk!» sa hun - og ble med.

Mehmet studerer ved et universitet i Istanbul og jobber aktivt med å utvikle det kurdiske språket Kurmanji på fritida. Vi møttes på universitetet der han studerte, og mens vi vandret rundt mellom bygningene, møtte vi ofte på venner av ham. De var alltid åpne om at de var kurdere, de snakket om foreningen de var med i eller tidsskriftet de ga ut om kurdiske språk, eller om andre temaer jeg kjente igjen fra kurdiske venner andre steder. Tonen var så åpen at jeg en stund karakteriserte universitetet som en lukket kurdisk sfære av noe spesiell art, et sted hvor det var akseptert å være åpen om kurdisk tilhørighet på tross 
av at den tyrkiske majoriteten var nettopp en majoritet også her.

En dag hadde vi begge tatt med bøker vi tenkte den andre kunne ha interesse av. Vel installert på tehuset rett utenfor universitetsporten med et glass sterk, søt te, trakk jeg bøkene opp av veska og begynte å forklare hva de handla om. De tok for seg røttene til kurdisk nasjonalisme, oversikter over situasjonen for kurdere i de fire landene den kurdiske befolkningen er delt mellom - forsidene og titlene var ikke til å ta feil av. «Det passer seg ikke her», sa Mehmet raskt og ba meg legge ned bøkene. Over i kopisenteret gikk han rett bort til en av de som jobbet der, viste ham bøkene og forklarte hva vi ville ha. Da klokka over døra ringte, la de bøkene ned i poser og gjorde opp. «De som kom inn er nasjonalister, de ville ikke likt det», forklarte Mehmet på vei ut av butikken. Mehmets håndtering av kurdisk identitet skiller seg fra Özlem og

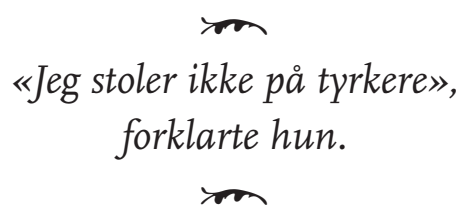

Gülhans. Mens de er åpne om sin kurdiske identitet på kafeer eller i avisa, altså på steder som er definert som trygge, er Mehmet hele tiden bevisst på omgivelsene der han befinner seg og veksler mellom en lukket kurdisk sfære og en offentlig sfære ut ifra hvem som er til stede heller enn hvor han er.

Ayfles liv skiller seg fra livene til Özlem, Gülhan og Mehmet på mange måter, også når det kommer til samhandling med den tyrkiske majoriteten. Ayfle var 20 da vi ble kjent, og hadde bare vært $i$ Istanbul i et par år. Hun bor i en gecekondu, direkte oversatt bygd over natta, i den anatoliske delen av Istanbul. Huset deres har tre rom og et kombinert kjøkken og bad. De har strøm bare sporadisk og har koblet seg på et vannrør på uortodokst vis slik at det er vann i en kran på kjøkkenet. De er seks voksne og sju barn, bare én har fast inntekt. Familien er fra landsbygda i de kurdiske områdene, men har vært på flyttefot i årevis fordi livet ble for vanskelig for dem der de var. De har migrert fra by til by, og tatt strøjobber med å høste avlinger etter årstid og behov. Ayfle har ingen skolegang, men hadde nettopp lært å lese og skrive på en NGo like ved familiens provisoriske hjem i Istanbul. Det var der vi ble kjent, og de første månedene var hun hos NGO-en åtte timer om dagen fem dager i uka for å lære å sy på symaskin. Organisasjonen tilbyr yrkestrening til unge migranter i området, flertallet av dem unge kvinner, for å gi dem muligheten til å få en jobb og en egen inntekt, og dermed i større grad være i kontroll over sitt eget liv, uavhengig av patriarkalske familiestrukturer.

Etter at kurset, som varte i et halvt år, var slutt, gikk Ayfle hjem - og ble der. Hun beklaget seg over situasjonen hun var havnet i. Hun var lei av å sitte hjemme med hendene i fanget, hun kom seg bare ut når hun skulle handle dagligvarer eller besøke slektninger i nabolaget. Hun var lei av å alltid ha brødrenes barn hengene i skjørtene og trengte rom for seg selv, sa hun. Likevel: når jeg spurte hvordan det gikk med jobbsøkingen, var svaret at hun var for lat til å jobbe. Vi var innom sjefen i NGo-en som ga den unge jenta en siste peptalk. «Ikke bare gå hjem og bli der!» sa hun gjentatte ganger. Hun sa til Ayfle at hun måtte oppsøke steder hvor hun kunne 
tenke seg å jobbe for å spørre om de trengte noen, og at hun måtte passe på å beholde en del av lønnen selv, selv om de eldre brødrene hennes sa at hun skulle gi det til dem. På vei hjem trakk Ayfle på skuldrene, og gjentok at hun var for lat. Hun hadde hatt jobber før, en i klesindustrien og en på en kveldsskole, hvor hun lagde og serverte te til lærere og studenter. Men hun sa hun ikke hadde vært komfortabel i noen av jobbene. Det var i det hele tatt få steder utenfor hjemmet hvor Ayfle ikke sa hun følte et ubehag. I situasjonene hvor hun måtte forholde seg til ikke-kurdere, som når noen spurte om klokka eller veien når hun var på vei hjem etter en dag på kurset, eller når hun var ute og handlet, var hun direkte fiendtlig og ba folk pakke seg vekk og ikke snakke til henne. «Jeg stoler ikke på tyrkere», forklarte hun.

Hvorfor hører dette eksempelet hjemme sammen med Özlem og Gülhans vandring fra kafé til kafé i Taksim og Mehmets manøvrering mellom identiteter på campus? De to unge kvinnene i avisa har jobb, de nyter stor frihet fra foreldrene sine, og de mestrer de kulturelle kodene i det tyrkiske samfunnet i så stor grad at de kan bevege seg fritt mellom sine kurdiske frirom. Mehmet, som i tillegg er godt utdannet, mestrer både de språklige og kulturelle kodene til majoriteten i så stor grad at han til en hver tid oppførerer seg slik situasjonen tillater. Han er åpent kurdisk når det er mulig, men underkommuniserer sin kurdiske identitet når det er folk til stede han ikke vet hvor han skal plassere, eller som i eksempelet over, når det er folk i nærheten som han vet er fiendtlig innstilt til landets kurdiske befolkning.

Ayfle, som ikke føler at hun mestrer verken språklige eller kulturelle koder i majoritetssamfunnet særlig godt, blir hjemme i det kurdiske frirommet som allerede er definert for henne av familien. På tross av at hun kjeder seg og gjerne vil ut, framstår det lille, overfylte huset som den beste løsningen for henne.

Ayfle, Özlem, Gülhan og Mehmet har ulike måter å håndtere sin kurdiske identitet i tyrkiskdominerte Istanbul. Det som er felles for dem er at de delene av identiteten deres som "avslører" dem som kurdere, underkommuniseres i møtet med den tyrkiskske majoriteten. Hvor godt de mestrer majoritetens koder, har avgjørende betydning for hvor mye de oppholder seg utenfor lukkede, kurdiske sfærer, og for i hvilken grad de selv greier å definere og etablere slike kurdiske frirom utenfor privatsfæren.

Hva er så konsekvensen av disse handlingsmønstrene? For Ayfle sin del er én konsekvens at hun knyttes tett til de patriarkalske strukturene i hjemmet. Hun tjener ikke egne penger og bygger seg i liten grad opp nettverk utover familien. At konflikten mellom tyrkere og kurdere har en slik effekt på livet hennes, kan ikke forklares bare ut fra at hun er kurdisk. At hun er en ung, ugift, uutdannet, fattig kvinne fra landsbygda, nyanserer bildet.

De fire eksemplene, så ulike de enn er, har en felles konsekvens som det er nødvendig å forstå mekanismene bak for å kunne etablere plattformen for dialog, som EUTCC oppfordret til. Sammenligningen med samenes situasjon i Norge på I960tallet antyder at disse innsiktene kan være gyldige i flere kontekster der etniske grupper er i konflikt. For når Istanbuls mange kurdere skjuler sin kurdiske identitet i hverdagslige interaksjoner med ikke-kurdere, er konsekvensen at den daglige 
samhandlingen på tvers av etniske skillelinjer blir usynlig. De hverdagslige og ukompliserte relasjonene på tvers av etniske skillelinjer ble forbigått i stillhet.

Mine kurdiske informanter var smertelig klar over at de skjulte sin kurdiske identitet i møter med majoriteten, for mange, blant annet, gjennom at de ikke kunne snakke morsmålet sitt utenfor hjemmet. De skjulte de delene av identiteten sin som ville blitt gjenkjent som kurdisk. Stigmaet ved å være kurder i Istanbul ble ikke realisert $\mathrm{i}$ disse dagligdagse situasjonene, fordi informantene mine ikke ga seg til kjenne som kurdere utenfor de lukkede kurdiske sfærene. Det ble ikke konfrontasjon eller dialog, fordi den ene parten ikke våger å gi seg til kjenne i dagliglivet. På tross av daglig samhandling, var det sjelden kurdere og tyrkere utvekslet tanker om forholdet mellom de etniske grupperingene i Tyrkia og det fiendtlige forholdet dem imellom. Kun under newrozfeiringa så jeg Istanbuls kurdere vise seg fram uten omsvøp, en feiring regissert av tyrkiske myndigheter.

$$
\cdot f \cdot
$$

I Artikkelen er basert på forfatterens masteroppgave: "All we want is our freedom. An intersectional approach to Kurdish lives in Istanbul", Universitetet i Oslo 2006.

2 Houston, Christopher: "Profane Intuitions: Kurdish Diaspora in the Turkish City - Istanbul," The Australian Journal of Anthropology, April 200I

3 Bruinessen, Martin van: "Between Guerrilla War and Political Murder: The Workers' Party of Kurdistan," Middle East Report, No. I53, Islam and the State, I988

4 Partiet heter nå DTP, Demokratik Toplum Partisi. Det har skiftet navn flere ganger de siste tiårene, etter å ha blitt presset til å legge seg selv ned for så å rekonstitueres.

5 "Turk Military Condemns Burning of Flag by Kurds": http:/ $/$ www.arabnews.com $/$ ?page $=4 \&$ section $=0 \&$ article $=$ $60883 \& \mathrm{~d}=23 \& \mathrm{~m}=3 \& \mathrm{y}=2005$ (Sist lest 27.0I.2007)

6 "Botched flag burning leads to patriotic backlash in Turkey”. Agence France-Presse, 24. mars 2005, referert fra http://www.kurd.org/newsletters/20050325091940 .html (Sist lest 27.0I.200I)

7 "Botched flag burning leads to patriotic backlash in Turkey". Agence France-Presse, 24. mars 2005, referert fra http://www.kurd.org/newsletters/20050325091940 .html (Sist lest 27.01.200I) 